\title{
A Survey of Service Oriented Architecture SYSTEMS TESTING
}

\author{
Ebrahim Shamsoddin-Motlagh ${ }^{1}$ \\ ${ }^{1}$ Computer Engineering Department, Faculty of Engineering, Science \& Research \\ Branch, Islamic Azad University, Tehran, Iran \\ e.shamsoddinesrbiau.ac.ir
}

\begin{abstract}
Service oriented architecture (SOA) is one of the latest software architectures. This architecture is created in direction of the business requirements and removed the gap between softwares and businesses. The software testing is the rising cost of activities in development software. SOA has different specifications and features proportion of the other software architectures. First this paper reviews SOA testing challenges and existing solution( $(s)$ for those challenges. Then that reports a survey of recent research to SOA systems testing, that covers both functional and non-functional testing. Those are presented for different levels of functional testing, including unit, integration, and regression testing.
\end{abstract}

\section{KEYWORDS}

Service Oriented Architecture Systems Testing, SOA

\section{INTRODUCTION}

Arasanjani, Borges and Holley define SOA as follows [1]: "SOA is the architectural style that supports loosely coupled services to enable business flexibility in an interoperable, technologyagnostic manner. SOA consists of a composite set of business-aligned services that support a flexible and dynamically re-configurable end-to-end business processes realization using interface-based service descriptions."

System services have features in the design and implementation, these features include: Service reusability, Standardized service contract, Service loose coupling, Service abstraction, Service composition, Service autonomy, Service statelessness and service discoverability capabilities.

The purpose of this paper is to find the testing challenges in the SOA systems and existing solution(s) and to review recent research in the test of SOA systems. The paper is structured as follows. Section 2 challenges are expressed in the SOA Testing, and then the solutions to eliminate or minimize problems are expressed in these challenges. Section 3 a review related work of SOA Testing. Finally, Section 4 summarizes the paper and outline suggests future research steps.

\section{SOA SYSTEMS TESTING CHALLENGES}

The SOA system has different nature and the specific characteristics than the traditional system of the test system; it's harder and needs more time. The test facilitates and abilities at the SOA system testing should be recognized and solution(s) should be presented for testing challenges.

DOI : $10.5121 /$ ijsea.2012.3602 
International Journal of Software Engineering \& Applications (IJSEA), Vol.3, No.6, November 2012

The key issues of testability limits of the SOA systems include: dynamicity and adaptiveness, lack of observability of the service code and structure, lack of control, lack of trust, new aspects of testing, test cost, different stakeholders $[2,3,4,5,6,7]$.

\subsection{Functional Testing Challenges}

The challenges of functional testing can be reported: All inputs and output may be very difficult to the system testing, Asynchronous in the SOA systems, rapid growth and large system (the development and management should be understood to be the test team) and need the tools and knowledge to work the system workflow [8].

The services don't have the service interface in unit testing [8], which this makes quality assurance team will have to be the implemented skills with to be able to produce good test, test objects, and the required test data. Another the service unit testing differences in inputloutput types with component testing and that complex [6], more test data generation techniques work on simple data, but in reality in complex systems such as SOA systems have complex inputs such as XML also used to inputs.

\subsection{Non-Functional Testing Challenges}

Non-functional properties of the system such as: availability, performance, applicability, maintenance capabilities, and portability. SOA has problems such as non-functional testing is impossible or difficult to determine a service workload parameters at service level agreement (SLA), the existing problems in the network and impact on system performance, system security (due to the decentralized system and the system is in the distributed system with different frameworks) [8]. The challenges of the test reliability can be reported [9]:

1- It may need a lot of time to test in the real execution as the faults may not occur in many situations.

2- Web services may involve many outside service providers who charge their service provided and it may a lot of cost.

3- The services in BPEL from different organizations should cooperate to achieve business goals. Their execution should be transactional.

4- Traditional faults generation techniques can only generate low level error regardless the business process, so that it makes difficult to test the whole process because the faults generated may not affect the business process intentionally.

\subsection{Existing Solutions}

The solutions of the functional testing challenges can be reported:

Among the proposed solutions for problems and challenges in the research include the functional testing procedures are updated at SOA Systems, and the existing methods are automated. The tools is used to performing complex actions and the integrity of system is able to management are produced. The monitoring system operated at all levels, and used the ESB capabilities for functional testing system. If needed and usability of other existing technologies (such as JMS middleware) was used.

Another solution is to improve the system new implementations [10]. Futures of the Internet need to make SOA testbed for large systems and reduce their cost of test. The testbed be required to validate and the integrity of the future Internet. The network should be loosely coupled, networks will be heterogeneous, and there will have capabilities in the program layer, and complexity will 
International Journal of Software Engineering \& Applications (IJSEA), Vol.3, No.6, November 2012

be greater in the composition. The systems need to automatic composition of services and management processes, there need to combine the testbed capabilities.

At the beginning of creating a production SOA system, the test team haven't high collaboration, but must be present to understand the goals and business processes, in order to properly and efficiently carry out the test, and that prevent the additional costs to the system development process.

\subsection{Summarized}

Table 1 shows the SOA Testing challenges with testing levels in the SOA systems.

Table 1. SOA Testing challenges with testing levels of the SOA systems.

\begin{tabular}{|c|c|c|c|c|c|}
\hline \multirow[b]{2}{*}{ Challenges } & \multicolumn{5}{|l|}{ Testing level } \\
\hline & $\begin{array}{l}\text { Functional } \\
\text { testing }\end{array}$ & $\begin{array}{l}\text { Unit } \\
\text { testing }\end{array}$ & $\begin{array}{l}\text { Integration } \\
\text { testing }\end{array}$ & $\begin{array}{l}\text { Regression } \\
\text { testing }\end{array}$ & $\begin{array}{l}\text { Non-functional } \\
\text { testing }\end{array}$ \\
\hline $\begin{array}{l}\text { dynamicity } \\
\text { and } \\
\text { adaptiveness }\end{array}$ & $\begin{array}{l}\text { Parallel testing } \\
\text { is hard, test } \\
\text { automation }\end{array}$ & - & $\begin{array}{l}\text { Integration will } \\
\text { be in the run of } \\
\text { system and } \\
\text { Deploy and } \\
\text { service } \\
\text { description testing } \\
\text { is hard }\end{array}$ & $\begin{array}{l}\text { Regression } \\
\text { testing is needed, } \\
\text { test automation }\end{array}$ & $\begin{array}{l}\text { Security of } \\
\text { system will be } \\
\text { low, test } \\
\text { automation }\end{array}$ \\
\hline $\begin{array}{l}\text { lack of } \\
\text { observability } \\
\text { of the service } \\
\text { code and } \\
\text { structure }\end{array}$ & $\begin{array}{l}\text { Stakeholders } \\
\text { Use of } \\
\text { different } \\
\text { platforms }\end{array}$ & $\begin{array}{l}\text { White } \\
\text { box } \\
\text { testing } \\
\text { unable in } \\
\text { service }\end{array}$ & $\begin{array}{l}\text { The testability } \\
\text { limits and } \\
\text { information is } \\
\text { low of services }\end{array}$ & $\begin{array}{l}\text { The determinate } \\
\text { of test time and } \\
\text { sections is } \\
\text { needed test are } \\
\text { hard }\end{array}$ & $\begin{array}{l}\text { Reliability will } \\
\text { be low and the } \\
\text { create of } \\
\text { parameters QoS } \\
\text { is hard }\end{array}$ \\
\hline $\begin{array}{l}\text { lack of } \\
\text { control }\end{array}$ & $\begin{array}{l}\text { Rapid } \\
\text { development } \\
\text { and } \\
\text { complexity of } \\
\text { system }\end{array}$ & - & $\begin{array}{l}\text { Distributed of } \\
\text { system and } \\
\text { Integration will } \\
\text { be in the run of } \\
\text { system }\end{array}$ & $\begin{array}{l}\text { The determinate } \\
\text { of test time and } \\
\text { sections is } \\
\text { needed test are } \\
\text { hard, Regression } \\
\text { testing is needed }\end{array}$ & $\begin{array}{l}\text { Efficiency, } \\
\text { security, and } \\
\text { reliability will } \\
\text { be low }\end{array}$ \\
\hline lack of trust & $\begin{array}{l}\text { The change of } \\
\text { system will be } \\
\text { in run and } \\
\text { complexity is } \\
\text { high }\end{array}$ & - & $\begin{array}{l}\text { The test will be in } \\
\text { the run of system } \\
\text { services }\end{array}$ & $\begin{array}{l}\text { The change of } \\
\text { system }\end{array}$ & $\begin{array}{l}\text { Parameters QoS } \\
\text { is offered, } \\
\text { reliability } \\
\text { challenges }\end{array}$ \\
\hline $\begin{array}{l}\text { new aspects } \\
\text { of testing }\end{array}$ & $\begin{array}{l}\text { The create of } \\
\text { new approach } \\
\text { and new tools }\end{array}$ & $\begin{array}{l}\text { The } \\
\text { create of } \\
\text { new } \\
\text { approach } \\
\text { and new } \\
\text { tools }\end{array}$ & $\begin{array}{l}\text { The create of new } \\
\text { approach and new } \\
\text { tools }\end{array}$ & $\begin{array}{l}\text { The create of } \\
\text { new approach } \\
\text { and new tools }\end{array}$ & $\begin{array}{l}\text { The create of } \\
\text { new approach } \\
\text { and new tools }\end{array}$ \\
\hline test cost & $\begin{array}{l}\text { The test cost } \\
\text { with } \\
\text { traditional } \\
\text { testing is high }\end{array}$ & $\begin{array}{l}\text { The test } \\
\text { cost with } \\
\text { traditional } \\
\text { testing is } \\
\text { high }\end{array}$ & $\begin{array}{l}\text { The test cost with } \\
\text { traditional testing } \\
\text { is high }\end{array}$ & $\begin{array}{l}\text { The test cost } \\
\text { with traditional } \\
\text { testing is high }\end{array}$ & $\begin{array}{l}\text { The test cost } \\
\text { with traditional } \\
\text { testing is high }\end{array}$ \\
\hline $\begin{array}{l}\text { different } \\
\text { stakeholders }\end{array}$ & $\begin{array}{l}\text { Software } \\
\text { platforms, } \\
\text { Distributed of } \\
\text { system }\end{array}$ & - & $\begin{array}{l}\text { The determinate } \\
\text { of change is hard }\end{array}$ & $\begin{array}{l}\text { The determinate } \\
\text { of change time is } \\
\text { hard }\end{array}$ & $\begin{array}{l}\text { Security and } \\
\text { reliability will } \\
\text { be low }\end{array}$ \\
\hline
\end{tabular}


International Journal of Software Engineering \& Applications (IJSEA), Vol.3, No.6, November 2012

\section{SOA SYSTEMS TESTING}

SOA system testing should be performed of aspects functional testing and non-functional testing, the functional testing has different levels, the levels include unit testing in individual services and the combined services, integration testing and regression testing.

This part of paper is checked SOA system testing of the functional aspects (in levels) and nonfunctional aspects, and then the test automation tools is described in the SOA system. Then automatic test data generation techniques are reviewed for traditional software. Finally, these results are shown in tables.

\subsection{Unit Testing}

Numbers of investigations in the unit testing have been active for test automation, in their attempted to automate process or processes of testing. The researches $[11,12,13,14,15,16]$ performed unit testing on WSDL file.

\subsection{Integration Testing}

Numbers of existing researches [17, 18, 19, 20, 21, 22, 23] performed BPEL-based testing in the system with operations graph.

In studies [24 and 25] implemented test at combining web services used to high level Petri net and specifications BPEL. You can generate test cases from web service automata (WSA) automatically [26]; WSA can be used to define the operational logic in BPEL.

Numbers of test frameworks have been prepared for SOA testing, than these are performed the SOA testing with the best way $[27,28]$.

The DFTT4CWS tools automatically find unusual data flow [29] and the test paths is generated data flow testing with all of cover criteria types. In reference [30], BPEL file is mapped DOM object tree to the EMF activities tree. The WebMov is set of tools modelling, evaluates and tests web services composition [31]. One paper was expressed computational strategy for the generation complete computational paths of BPEL based on Tabu Search and Genetic Algorithms to generate test data [32].

The research [33] provided an approach to design test cases based on functional properties of high-level business process model. The study [34] proposed an approach for reducing the costs to test such applications, and how can semantic stubs enable the client test suite to be partitioned into subsets, some of which don't use to execute remote services. Model driven approach is presented in [35], this approach to generate executable test cases from the given express business processes.

\subsection{Regression Testing}

Researches [36, 37] are proposed an approach to determine the changes use to extensible BPEL flow graph (XBFG) of control flow and to compare the paths in a new version of service composition with the old version.

Testing rules and monitoring rules include: checking the functional characteristics services, checking quality of service (QoS), checking interoperability services and service evolution [38]. 
International Journal of Software Engineering \& Applications (IJSEA), Vol.3, No.6, November 2012

\subsection{Non-Functional Testing}

Non-functional requirements include [39]: the needed data to fulfill the monitoring goal is intercepted. Monitoring mechanisms attempt the performance isn't influenced of unmonitored elements and performance is influenced of the monitored elements remains to be minimal. The changes responses are in the monitoring goal and environment topology. Instrumentation must be transparent and performed on demand.

System security is one of the characteristics non-functional SOA systems. The paper [40] presented a preliminary approach towards an evaluation framework for SOA security testing tools.

A research proposes a technique on how do reliability test define of composite service in BPEL from the view of business semantics with little cost using fault injection [9]. This paper focus on how the reliability problems find relate with business process, the called semantics as the problems are not pure coding error but faults related to business process. In addition, the behaviour of composite services in BPEL is analyzed when there are faults in the orchestrated services invoked.

\subsection{Automatic testing tools}

Numbers of existing produced tools was created to test SOA systems automatically. For example TASSA is a framework for automatic testing in functional and non-functional specifications of service-based applications [41]. It provides end-to-end testing of Service layer, Service Composition and coordination and business process. Another tool is WSOTF presented for the automated testing [42]. WSOTF is an automatic conformance testing tool with timing constraints from a formal specification of web services composition that is implemented by an online testing algorithm.

In the study [43] is expressed test approach described in BPEL web service composition. The paper [44] is proposed to generate a testbed for service-oriented systems that takes into account a mobility model of nodes in the network which the accessed services are deployed.

The study [45] is a framework and its supporting tool for automatically generating and executing web-service requests and analyzing the subsequent request-response pairs.

The study [46] is proposed an approach to combine the accessibility technologies in graphical applications (GAPs) for a visualization mechanism enables nonprogrammers to generate unit test cases in web services by drag-and-drop operations on graphical user interface (GUI). In the reference [47] is testing techniques to generate a set of test cases for web services automatically. The techniques presented here explore data perturbation of Web services messages upon data types, integrity and consistency.

\subsection{Summarized}

In the paper [48] is expressed a survey to explore cloud services testing methods. The paper [49] is expressed a review to identify SOA testing researches with dynamic binding, that paper performed manually and automatically search in journals, conferences and etc.

Methods described in Table 2 with different levels of test coverage, SOA system testing and see in them. In A service may be provided in the composition of services using BPEL file, the reason 
International Journal of Software Engineering \& Applications (IJSEA), Vol.3, No.6, November 2012

test on the some parts of this table is on the integration testing (the BPEL file) also put on the unit testing capabilities.

Table 2. SOA systems testing Methods at levels testing

\begin{tabular}{|c|c|c|c|c|}
\hline \multirow[b]{2}{*}{ Method } & \multicolumn{4}{|c|}{ Level Testing } \\
\hline & $\begin{array}{l}\text { Unit } \\
\text { Testing }\end{array}$ & $\begin{array}{l}\text { Integration } \\
\text { Testing }\end{array}$ & $\begin{array}{l}\text { Regression } \\
\text { Testing }\end{array}$ & $\begin{array}{l}\text { Non- } \\
\text { Functional } \\
\text { Testing }\end{array}$ \\
\hline $\begin{array}{l}\text { DOM tree }[11,14] \text {, } \\
\text { DbC [13, 16], WS- } \\
\text { TAXI [15], GAP [46], } \\
\text { GenAutoWS [47], } \\
\text { [45] }\end{array}$ & $\begin{array}{l}\text { Generate } \\
\text { test cases } \\
\text { by WSDL }\end{array}$ & - & - & - \\
\hline SAT Solver [21] & - & $\begin{array}{l}\text { Generate test cases } \\
\text { by processes and } \\
\text { user activity }\end{array}$ & $\begin{array}{l}\text { Use to save } \\
\text { test cases }\end{array}$ & - \\
\hline $\begin{array}{l}\text { CPM [33], [20, 27, 28, } \\
29,34,35]\end{array}$ & - & $\begin{array}{l}\text { Generate test cases } \\
\text { for processes } \\
\text { business }\end{array}$ & - & - \\
\hline $\begin{array}{l}\text { SXM [22, 23], BTA } \\
\text { [25], TestGen-IF [43], } \\
\text { WSA [26], [17, 18, } \\
19,24,30], \text { Tabu [32] }\end{array}$ & $\begin{array}{l}\text { BPEL } \\
\text { testing }\end{array}$ & $\begin{array}{l}\text { Generate test cases } \\
\text { for BPEL service }\end{array}$ & - & - \\
\hline TASSA [41] & $\begin{array}{l}\text { Layer } \\
\text { service } \\
\text { testing }\end{array}$ & $\begin{array}{l}\text { Generate test cases } \\
\text { at orchestration } \\
\text { and BPEL service }\end{array}$ & - & $\begin{array}{l}\text { Layers testing, } \\
\text { Coordination } \\
\text { and service } \\
\text { composition } \\
\end{array}$ \\
\hline WSOTF [42] & $\begin{array}{l}\text { Analysis } \\
\text { WSDL }\end{array}$ & $\begin{array}{l}\text { Generate test cases } \\
\text { at specification } \\
\text { system }\end{array}$ & - & 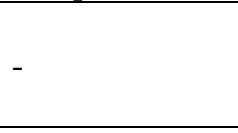 \\
\hline XBFG [36,37] & - & - & $\begin{array}{l}\text { Select test } \\
\text { cases }\end{array}$ & - \\
\hline [40] & - & - & - & Security \\
\hline [9] & - & - & - & Reliability \\
\hline [44] & - & - & - & $\begin{array}{l}\text { Generate } \\
\text { specification in } \\
\text { mobile system } \\
\text { model }\end{array}$ \\
\hline
\end{tabular}

\section{Conclusions}

The part of tow this paper was expressed challenges and limitations of the SOA systems testing, and the existing solutions to solve some of them. The SOA systems testing challenges include: dynamicity and adaptiveness, lack of observability of the service code and structure, lack of control, lack of trust, new aspects of testing, test cost, different stakeholders. The part of three this paper was expressed SOA systems testing at two aspects of functional testing and non-functional testing. The functional testing was investigated in three different parts of the unit, integration and regression. In the last of chapters the results of these researches showed in the relevant tables. 
Manually test cases generation and manually test operations are a difficult and time consuming and the dynamic nature of the SOA systems cause the test cases is generated after some time lose their usability. To resolve this problem need to create a dynamic and automatic way to generate test cases in orchestration of SOA. Future works will propose specific approaches for specific software in the software logic or improve existing approaches for specific software. Another create test cases generation framework for SOA systems. Future work can be integration of available tools.

\section{ACKNOWLEDGEMENTS}

The author would like to thank specially Dr. Seyed Hasan Mirian Hossienabadi who has extended his support for successful completion of this paper.

\section{REFERENCES}

[1] Torry Harris Business Solutions (THBS) Company (2007). SOA Test Methodology [White paper]. Retrieved from www.thbs.com/pdfs/SOA_Test_Methodology.pdf

[2] Hewlett-Packard (HP) Development Company (2007, March). Testing service oriented architecture applications and services [White paper]. Retrieved from http://i.i.com.com/cnwk.1d/html/itp/HP_4AA1-1389ENW_Testing_SOA_WP_5966.pdf

[3] IBM Corporation Software Group (2007, May). Testing SOA applications with IBM Rational quality management. White paper. from ftp://public.dhe.ibm.com/software/rational/web/whitepapers/10708268_Testing_SOA_WP_acc.pdf

[4] Greiler, M., Gross, H. G., Nasr, K. A. (2009). Runtime Integration and Testing for Highly Dynamic Service Oriented ICT Solutions - An Industry Challenges Report. 2009 Testing: Academic and Industrial Conference - Practice and Research Techniques, 51-55. Doi: 10.1109/TAICPART.2009.16

[5] Bertolino, A., \& Polini, A. (2009). SOA Test Governance: enabling service integration testing across organization and technology borders. IEEE International Conference on Software Testing Verification and Validation Workshops, 277-286. Doi: 10.1109/ICSTW.2009.39

[6] Canfora, G., \& Penta, M. D. (2008). Service Oriented Architectures Testing A Survey. This work is partially founded by the European Commission VI Framework IP Project SeCSE (Service Centric SystemEngineering) (http://secse.eng.it), Contract No. 511680, and by the Italian Department of University and Research (MIUR) FIRB Project ARTDECO. Retrieved from http://rcost.unisannio.it/rcost_www/mdipenta/papers/lncs09.pdf

[7] Canfora, G., \& Penta, M. D. (2006, March|Appril). Testing Services and Service-Centric Systems: Challenges and Opportunities. IEEE Computer Society, 10-17. Doi: 10.1109/MITP.2006.51.

[8] Ribarov, L., Manova, I., Ilieva, S. (2007, September 21-23). TESTING IN A SERVICE-ORIENTED WORLD. The International Conference on Information Technologies (InfoTech-2007), Bulgaria vol. 1, 1-10. Retrieved from http://dspace.ou.nl/bitstream/1820/1067/1/TestingInAServiceOrientedWorld.pdf

[9] Wang, Y., Ishikawa, F., Honiden, S. (2010). Business Semantics Centric Reliability Testing for Web Services in BPEL. IEEE 6th World Congress on Services, 237-244. Doi: 10.1109/SERVICES.2010.88

[10] Magedanz, T., Schreiner, F., Wahle, S. (2009). Service-Oriented Testbed Infrastructures and CrossDomain Federation for Future Internet Research. 2009 IFIP/IEEE Intl. Symposium on Integrated Network Management - Workshops, 101-106. Doi: 10.1109/INMW.2009.5195944

[11] Bai, X., Dong, W., Tsai, W. T., Chen, Y. (2005). WSDL-Based Automatic Test Case Generation for Web Services Testing. 2005 IEEE International Workshop on Service-Oriented System Engineering (SOSE'05), 1-6. Doi: 10.1109/SOSE.2005.43

[12] Jiang, Y., Li, Y. N., Hou, S. S., Zhang, L. (2009). Test-Data Generation for Web Services Based on Contract Mutation. 2009 Third IEEE International Conference on Secure Software Integration and Reliability Improvement SSIRI 2009 Short Paper, 281-286. Doi: 10.1109/SSIRI.2009.49 
International Journal of Software Engineering \& Applications (IJSEA), Vol.3, No.6, November 2012

[13] Ma, C., Du, C., Zhang, T., Hu, F., Cai, X. (2008). WSDL-Based Automated Test Data Generation for Web Service. International Conference on Computer Science and Software Engineering, 731-737. Doi: 10.1109/CSSE.2008.790

[14] Dong, W. (2009). Testing WSDL_based Web Service Automatically. World Congress on Software Engineering, 521-525. Doi: 10.1109/WCSE.2009.133

[15] Bartolini, C., Bertolino, A., Marchetti, E. (2009). WS-TAXI: a WSDL-based testing tool for Web Services. International Conference on Software Testing Verification and Validation, 326-335. Doi: 10.1109/ICST.2009.28

[16] Noikajana, S., \& Suwannasart, T. (2009). An Improved Test Case Generation Method for Web Service Testing from WSDL-S and OCL with Pair-wise Testing Technique. 33rd Annual IEEE International Computer Software and Applications Conference, 115-123. Doi: 10.1109/COMPSAC.2009.25

[17] Mei, L., Chan, W.K., Tse, T.H. (2008, May 10-18). Data Flow Testing of Service-Oriented Workflow Applications, ICSE '08, Leipzig, Germany, 371-380. Doi: 10.1145/1368088.1368139

[18] Lertphumpanya, T., \& Senivongse, T. (2008, May). Basis Path Test Suite and Testing Process for WS-BPEL. WSEAS TRANSACTIONS on COMPUTERS. ISSN: 1109-2750, Issue 5, Volume 7, 483-496. Retrieved from www.wseas.us/e-library/transactions/computers/2008/26-156.pdf

[19] Yuan, Y., Li, Z., Sun, W. (2006). A Graph-search Based Approach to BPEL4WS Test Generation. Proceedings of the International Conference on Software Engineering Advances (ICSEA'06). Doi: 10.1109/ICSEA.2006.261270

[20] Bartolini, C., Bertolino, A., Elbaum, S., Marchetti, E. (2011). Bringing white-box testing to Service Oriented Architectures through a Service Oriented Approach. The Journal of Systems and Software, 84, 655-668. Doi:10.1016/j.jss.2010.10.024

[21] Radhakrishnan, K., \& Podorozhny, R. (2009, February 16). Automatic test case generation for web service processes using a SAT solver (Report Number TXSTATE-CS-TR-2009-13). https://digital.library.txstate.edu/bitstream/handle/10877/2581/fulltext.pdf

[22] Ma, C., Wu, J., Zhang, T., Zhang, Y., Cai, X. (2008) Automatic Test Case Generation for BPEL Using Stream X-Machine. International Journal of u- and e- Service, Science and Technology, 27-36. Retrieved from http://www.sersc.org/journals/IJUNESST/vol1_no1/papers/04.pdf

[23] Ma, C., Wu, J., Zhang, T., Zhang, Y., Cai, X. (2008). Testing BPEL with Stream X-machine. International Symposium on Information Science and Engieering, 578-582. Doi: 10.1109/ISISE.2008.201

[24] Dong, W.L., YU, H., Zhang, Y.B. (2006). Testing BPEL-based Web Service Composition Using High-level Petri Nets. Proceedings of the 10th IEEE International Enterprise Distributed Object Computing Conference (EDOC'06), 441 - 444. Doi: 10.1109/EDOC.2006.59

[25] Dong, W. (2009). Test Case Generation Method for BPEL-based Testing. 2009 International Conference on Computational Intelligence and Natural Computing, 467-470. Doi: 10.1109/CINC.2009.229

[26] Zheng, Y., Zhou, J., Krause, P. (2007, September). An Automatic Test Case Generation Framework for Web Services. JOURNAL OF SOFTWARE, VOL. 2, NO. 3, 64-77. Retrieved from http://epubs.surrey.ac.uk/1975/1/fulltext.pdf

[27] Lee, Y. (2009). 2-Layered SOA Test Framework Based on BPA1-Simulated Event. Fifth International Joint Conference on INC, IMS and IDC, 1058-1063. Doi: 10.1109/NCM.2009.337

[28] Mei, L. (2009, May 16-24). A Context-Aware Orchestrating and Choreographic Test Framework for Service-Oriented Applications. ICSE'09, Vancouver, Canada, 371-374. Doi: 10.1109/ICSECOMPANION.2009.5071024

[29] Hou, J., \& Xu, L. (2009). DFTT4CWS: A Testing Tool for Composite Web Services Based on DataFlow. Sixth Web Information Systems and Applications Conference, 62-67. Doi: 10.1109/WISA.2009.19

[30] Huang, J, \& Gong, Y. (2010). An EMF Activity Tree Based BPEL Defect Pattern Testing Method. 2nd International Conference on Computer Engineering and Technology, 7, 468-471. Doi: 10.1109/ICCET.2010.5485536

[31] Cavalli, A., Cao, T.D., Mallouli, W., Martins, E., Sadovykh, A., Salva, S., Za“1di, F. (2010).WebMov A dedicated framework for the modelling and testing of Web Services composition. IEEE International Conference on Web Services, 377-384. Doi: 10.1109/ICWS.2010.24

[32] Bo, Y., Ye-mei, Q., Ge, Y., Chang, G. (2009). Tabu Search and Genetic Algorithm to Generate Test Data for BPEL Program. Computational Intelligence and Software Engineering (CiSE), 1-6. Doi: 10.1109/CISE.2009.5363674 
International Journal of Software Engineering \& Applications (IJSEA), Vol.3, No.6, November 2012

[33] Bakota, T., Beszédes, Á., Gergely, T., Gyalai, M. I., Gyimóthy, T., Füleki, D. (2008). SemiAutomatic Test Case Generation from Business Process Models. This research was supported in part by the Hungarian national grants RET-07/2005, OTKA K-73688 and TECH_08-A2/2-2008-0089 SZOMIN08. Retrieved from http://www.inf.uszeged.hu/ beszedes/research/bakota09_semiautomatic.pdf

[34] Mani, S., Sinha, V. S., Sinha S. Dhoolia, P. Mukherjee, D. Chakraborty, S. (2009). Efficient Testing of Service-Oriented Applications Using Semantic Service Stubs. IEEE International Conference on Web Services, 197-204. Doi: 10.1109/ICWS.2009.40

[35] Yuan, Q., Wu, J., Liu, C., Zhang, L. (2008). A Model Driven Approach Toward Business Process Test Case Generation. 10th International Symposium on Web Site Evolution (WSE), 41-44. Doi: 10.1109/WSE.2008.4655394

[36] Li, B., Qiu, D., Ji, S., Wang, D. (2010). Automatic Test Case Selection and Generation for Regression Testing of Composite Service Based on Extensible BPEL Flow Graph. 26th IEEE International Conference on Software Maintenance in TimiSoara, Romania, 1-10. Doi: 10.1109/ICSM.2010.5609541

[37] Li, B., Qiu, D., Leung, H., Wang, D. (2012). Automatic test case selection for regression testing of composite service based on extensible BPEL flow graph. The Journal of Systems and Software Volume 85, Issue 6, 1300-1324. Doi:10.1016/j.jss.2012.01.036

[38] Canfora, G., \& Penta, M. D. (2006). SOA Testing and Self-Checking. International Workshop on Web Services Modeling and Testing (WS-MaTe 2006), 3-12. Retrieved from http://www.selab.isti.cnr.it/ws-mate/Canfora_WS-MaTe.pdf

[39] Zmudaa, D., Psiuk, M., Zielinski, K. (2010). Dynamic monitoring framework for the SOA execution environment. International Conference on Computational Science (ICCS 2010), 1, 125-133. Doi:10.1016/j.procs.2010.04.015

[40] Kabbani, N., Tilley, S., Pearson, L. (2010, April 5-10). Towards an Evaluation Framework for SOA Security Testing Tools. SysCon 2010 - IEEE International Systems Conference San Diego, CA, 438443. Doi: 10.1109/SYSTEMS.2010.5482322

[41] Ilieva, S., Pavlov, V., Manova, I. (2010). A Composable Framework for Test Automation of ServiceBased Applications. 2010 Seventh International Conference on the Quality of Information and Communications Technology, 286-291. Doi: 10.1109/QUATIC.2010.54

[42] Cao, T.D., Felix, P., Castanet, R. (2010). WSOTF An Automatic Testing Tool for Web Services Composition. Fifth International Conference on Internet and Web Applications and Services, 7-12. Doi: 10.1109/ICIW.2010.9

[43] Lallali, M., Zaidi, F., Cavalli, A., Hwang, I. (2008). Automatic Timed Test Case Generation for Web Services Composition. Sixth European Conference on Web Services, 53-62. Doi: 10.1109/ECOWS.2008.14

[44] Bertolino, A., Angelis, G.D., Lonetti, F., Sabetta, A. (2008). Automated Testbed Generation for Service-oriented Mobile Applications. 34th Euromicro Conference Software Engineering and Advanced Applications, 321-328. Doi: 10.1109/SEAA.2008.33

[45] Martin, E., Basu, S., Xie, T. (2007). Automated Testing and Response Analysis of Web Services. IEEE International Conference on Web Services (ICWS), 647-654. Doi: 10.1109/ICWS.2007.49

[46] Conroy, K. M., Grechanik, M., Hellige, M., Liongosari, E. S., Xie, Q. (2007). Automatic Test Generation From GUI Applications For Testing Web Services. Software Maintenance, IEEE International Conference on ICSM, 345-354. Doi: 10.1109/ICSM.2007.4362647

[47] Melo A. C.V. d., \& Silveira, P. (2011). Improving data perturbation testing techniques for Web services. Information Sciences 181, 600-619. Doi:10.1016/j.ins.2010.09.030

[48] Mohammad, A. F., \& Mcheick, H. (2011). Cloud Services Testing An Understanding. The 2nd International Conference on Ambient Systems, Networks and Technologies, Procedia Computer Science, 5, 513-520. Doi:10.1016/j.procs.2011.07.066

[49] Palacios, M., Garcio-Fanjul, J., Tuya, J. (2011). Testing in Service Oriented Architectures with dynamic binding: A mapping study. Information and Software Technology, 53, 171-189. Doi:10.1016/j.infsof.2010.11.014 